\title{
SPEKTA
}

Jurnal Pengabdian Kepada Masyarakat : Teknologi dan Aplikasi

Journal homepage :

http://journal2.uad.ac.id/index.php/spekta

\section{MEWUJUDKAN DESA INOVASI TEKNOLOGI MELALUI PENGGUNAAN KOMPOSIT (RESIN DAN SERBUK LIMBAH BAWANG) DI DESA BANGSRI DAN DESA PESANTUNAN KABUPATEN BREBES}

\author{
Irfan Santosa ${ }^{1, *}$, Ahmad Farid ${ }^{1}$, Mobinta Kusuma ${ }^{2}$ \\ ${ }^{1}$ Program Studi Teknik Mesin, Universitas Pancasakti Tegal, Kota Tegal, Jawa Tengah, Indonesia \\ ${ }^{2}$ Program Studi Pendidikan IPA, Universitas Pancasakti Tegal, Kota Tegal, Jawa Tengah, Indonesia
}

\begin{tabular}{l}
\hline ARTICLE INFO \\
\hline \\
Received : December 2020 \\
Revised : January, 2021 \\
Accepted : February, 2021 \\
\hline
\end{tabular}

Keywords:

Composite;

Resin;

Onion waste.

ABSTRACT
The area of harvested shallots in Brebes is $60.82 \%$ of the
total harvested area in Central Java Province.
Production of shallots in 2018 reached 10,519,484
quintals. Pesantunan Village, Wanasari District, has a
high productivity of 121.544 quintals/Ha and Bangsri
Village has a productivity of 98.28 quintals/Ha. The
abundant potential of onions also has an impact on the
abundant onion waste, so that the potential for this onion
waste will be made a composite as the embodiment of the
Innovation Village. The purpose of this community
service activity is to create a Technology Innovation
Village to community groups in Pesantunan and Bangsri
Villages regarding the use of onion waste into a
composite.The method offered is divided into two, namely
Soft Program and Hard Program.The result of the
composite technology innovation village program,
number of participants in the Pesantunan Village was 25
from the "Santun Asri" community group and 15 people
in the Bangsri Village from the "Bumdes" membership.
Participants were provided with a soft program
including waste management and technology innovation
villages in the composite field. Participants were also
provided with a Hard Program, is practicing making
composites with waste onions.

\section{PENDAHULUAN}

Kabupaten Brebes masih menjadi dominasi Kabupaten yang dapat memenuhi kebutuhan nasional sebesar 30\% dari kebutuhan nasional per tahun (Suhono, 2016). Kabupaten Brebes memiliki 17 Kecamatan dan 10 Kecamatan diantaranya

\footnotetext{
* Corresponding author.

E-mail address: ci_ulya@yahoo.co.id

https://doi.org/10.12928/J.spekta.v2i2.3236
} 
Vol. 2, No. 1, Juni 2021

memproduksi bawang merah sehingga bawang merah di Kabupaten Brebes melimpah. Luas panen yang dimiliki oleh Kabupaten Brebes sebesar 60,82\% dari total luas panen di Provinsi Jawa Tengah. Produksi bawang merah di Kabupaten tersebut pada tahun 2014 mencapai 7.519.484 kuintal. Besar produksi bawang merah di Kabupaten Brebes berasal dari beberapa Kecamatan. Kecamatan Wanasari merupakan kecamatan yang memiliki luas panen $7.075 \mathrm{Ha}$ dan produksi tertinggi sebesar 1.025.680 kuintal (Badan Pusat Statistik Kabupaten Brebes, 2015). Tabel 1 merupakan data luas lahan dan produksi bawah merah di Kecamatan Wanasari.

Tabel 1. Data Luas Lahan dan Produksi Bawang Merah setiap desa di Kecamatan Wanasari.

\begin{tabular}{clrrr}
\hline No & $\begin{array}{c}\text { Desa di Kecamatan } \\
\text { Wanasari }\end{array}$ & $\begin{array}{c}\text { Luas lahan } \\
(\mathrm{Ha})\end{array}$ & $\begin{array}{c}\text { Produksi } \\
(\mathrm{Kw})\end{array}$ & $\begin{array}{r}\text { Produktivitas } \\
(\mathrm{Kw} / \mathrm{Ha})\end{array}$ \\
\hline 1 & Tanjung Sari & 497,231 & 38.300 & 77,026 \\
2 & Sawojajar & 359,900 & 10.200 & 28,341 \\
3 & Pebatan & 328,470 & 15.800 & 48,102 \\
4 & Jagalempeni & 292,880 & 12.300 & 41,997 \\
5 & Siasem & 289,400 & 34.000 & 117,484 \\
6 & Dukuh Wiringi & 150,680 & 11.200 & 74,329 \\
7 & Dumeling & 168,570 & 5.720 & 33,932 \\
8 & Glonggong & 181,960 & 8.200 & 45,065 \\
9 & Keboledan & 100,410 & 9.600 & 95,608 \\
10 & Kertabesuki & 113,510 & 3.300 & 29,072 \\
11 & Klampok & 284,930 & 22.350 & 78,440 \\
12 & Kupu & 190,720 & 6.600 & 34,606 \\
13 & Lengkong & 85,500 & 7.060 & 82,572 \\
14 & Pesantunan & 102,020 & 12.400 & 121,544 \\
15 & Sidamulya & 210,620 & 16.300 & 77,391 \\
16 & Sigentong & 169,808 & 19.100 & 112,479 \\
17 & Sisalam & 136,570 & 7.290 & 53,379 \\
18 & Siwungkuk & 77,450 & 4.300 & 55,519 \\
19 & Tegalgandu & 198,760 & 10.250 & 51,569 \\
20 & Wanasari & 198,210 & 18.800 & 94,840 \\
\hline Jumlah & $4.137,599$ & 273.070 & \\
\hline
\end{tabular}

Berdasarkan Tabel 1 di Kecamatan Wanasari produksi bawang melimpah dan disertai limbah bawang juga melimpah. Akibatnya kesulitan membuang limbah bawang para petani biasanya membakar limbah tersebut sehingga mengakibatkan polusi di sekitar lingkungan. Maka perlunya inovasi teknologi yang memanfaatkan limbah bawang tersebut. Adapun yang akan diangkat dalam kegiatan ini adalah limbah bawang sebagai komposit. Kegiatan ini dikemas dengan tema Desa Inovasi Teknologi dimana sesuai Peraturan Menteri Desa PDTT No 23 Tahun 2017 tentang Pengembangan dan penerapan Teknologi Tepat Guna Dalam Pengelolaan Sumber daya alam desa dengan melihat potensi sumber daya alam dan sumber daya manusianya. Pemanfaatan limbah bawang menjadi sebuah komposit merupakan aplikasi teknologi tepat guna yang sesuai kebutuhan masyarakat, dapat menjawab permasalahan masyarakat, tidak merusak lingkungan, dapat dimanfaatkan dan diperlihara oleh masyarakat dengan mudah serta menghasilkan nilai tambah dari aspek ekonomi dan lingkungan. Kegiatan ini akan fokus di 2 desa yaitu Desa 
Vol. 2, No. 1, Juni 2021

Pesantunan Kecamatan Wanasari dan Desa Bangsri Kecamatan Bulakamba, Brebes, Jawa Tengah, Indonesia. Kedua Desa ini berjarak kurang lebih $7 \mathrm{Km}$ ke arah barat dari ibu kota Kabupaten Brebes. Desa Bangsri adalah desa terluas di Kecamatan Bulakamba dan berada di Jalur pantura yang juga sebagai penghasil bawang. Produksi bawang merah melimpah maka akan menghasilkan sampah/ limbah dari bawang tersebut. Biasanya limbah/sampah dari bawang merah tersebut dikumpulkan dan dibakar atau bahkan hanya tergelak berserak di tanah. Padahal limbah/ sampah yang berupa kulit bawang mempunyai banyak manfaat yaitu sebagai obat berbagai penyakit, insektisida alami, pewarna alami, bahan baku kerajinan dan penyubur tanaman.

Banyaknya manfaat dari limbah bawang tersebut maka perlu adanya inovasi dan kreativitas yang mampu memberikan solusi dan upaya dalam meningkatkan pengetahuan, produktivitas dan kesejahteraan masyarakat. Salah satu program yang saat ini sedang dikembangkan dari Pemerintah Kabupaten Brebes melalui Baperlitbangda adalah Desa Inovasi. Melalui program desa inovasi ini dengan bekerjasama akademisi perguruan tinggi memberikan solusi dari permasalahan limbah bawang merah yaitu sebagai bahan baku dalam permbuatan produk kerajinan pada peralatan rumah tangga (Arfan et al., 2020).

Dipilihnya Desa Bangsri dan Pesantunan dalam program Desa Inovasi ini karena masing-masing memiliki potensi hasil alam/ sumber daya alam (SDA) dari pertanian bawang merah yang melimpah dan memiliki Sumber Daya Manusia (SDM) yang berpotensi untuk maju, semangat dalam berkarya, inovatif dan sudah terorganisir dalam wadah pengelolaan sampah yaitu Bank Sampah dan Karang Taruna sehingga dengan harapan akan lebih mudah program ini terlaksanakan sebagai pilot project untuk pengembangan desa-desa lainnya.

Salah satu program desa inovasi yang dikembangkan dari pengelolaan sampah bawang merah adalah menggunakan teknologi resin komposit dengan campuran serat/ serbuk limbah daun bawang yang kemudian dituangkan atau dibentuk menjadi sebuah produk menggunakan cetakan-cetakan silicon. Pencampuran serbuk limbah daun bawang diharapkan mampu untuk meningkatkan kekuatan struktur pada material hasil cetakan. Komposit adalah suatu jenis bahan baru hasil rekayasa yang terdiri dari dua atau lebih bahan dimana sifat masing-masing bahan berbeda satu sama lainnya baik itu sifat kimia maupun fisikanya dan tetap terpisah dalam hasil akhir bahan tersebut (bahan komposit). Dengan adanya perbedaan dari material penyusunnya maka komposit antar material harus berikatan dengan kuat, sehingga perlu adanya penambahan wetting agent.

Beberapa definisi komposit sebagai berikut:

a. Tingkat dasar: pada molekul tunggal dan kisi kristal, bila material yang disusun dari dua atom atau lebih disebut komposit (contoh senyawa, paduan, polymer dan keramik).

b. Mikrostruktur: pada kristal, phase dan senyawa, bila material disusun dari dua phase atau senyawa atau lebih disebut komposit (contoh paduan $\mathrm{Fe}$ dan $\mathrm{C}$ ).

Material yang disusun dari campuran dua atau lebih penyusun makro yang berbeda dalam bentuk dan/atau komposisi dan tidak larut satu dengan yang lain disebut material komposit (Soemardi, 2009; Sirait, 2010). Serat pelepah gebang sebagai bahan baku komposit polimer dapat bernilai ekonomis dan mudah diperoleh dalam jumlah banyak (Abanat et al, 2012). Tanaman Mendong termasuk tanaman yang tumbuh di lahan basah, di daerah yang berlumpur dan memiliki air yang cukup, dan biasanya tumbuh dengan panjang lebih kurang $100 \mathrm{~cm}$ (Suryanto et al, 2013). Sampai saat ini pemanfaatan sabut kelapa masih terbatas pada industri mebel ataupun kerajinan rumah tangga dan belum 
Vol. 2, No. 1, Juni 2021

diolah menjadi produk teknologi. Tanaman nanas sangat luas penyebarannya, sehingga dapat ditemukan pada daerah tropik dan daerah subtropik maupun daerah yang mempunyai keadaan iklim basah serta kering (Setyawan et al., 2012). Serat sabut kelapa memiliki potensi sebagai penguat bahan baru pada komposit polimer (Amin \& Samsudi, 2010).

Kelapa menempati urutan kedua untuk tanaman budidaya setelah padi. Selain daging buah, bagian lain dari kelapa juga memiliki nilai ekonomis seperti daun kelapa, batang pohon dan tempurung, tapi sabut kelapa kurang mendapat perhatian (Astika, 2013). Bahan wadah ikan yang terbuat dari material komposit berpenguat serat pisang abaca. Komposit dibentuk menjadi anyaman tenunan dan anyaman tikar. Dari hasil pengujian tarik diperoleh kekuatan tarik rata-rata sebesar $9 \mathrm{MPa}$ dan tegangan luluh ratarata sebesar 6,835 MPa. Sedangkan hasil perhitungan pembebanan plat diperoleh tebal kompsit minimum sebelum terjadi defleksi $3 \mathrm{~mm}$ yaitu 3,27 mm (Dhiki Ramadhani, 2011). Material komposit dengan panjang serat jerami $20 \mathrm{~mm}$ memiliki kekuatan tarik rata-rata 18,99 MPa dan kekuatan bending rata-rata 98,05 $\mathrm{MPa}$, sedangkan untuk material komposit dengan panjang serat jerami $30 \mathrm{~mm}$ memiliki kekuatan tarik rata-rata 19,68 MPa dan kekuatan bending rata-rata 98,86 MPa. Fraksi volume setelah material komposit jadi adalah 35\% jerami (Wahdan Kurniawan, 2011). Nilai kekuatan tarik rata-rata disetiap lapisan komposit serat kulit pohon terap bervariasi yaitu untuk serat 1 lapis memiliki kekuatan 10,46 $\mathrm{MPa}$, serat 2 lapis dengan kekuatan tarik 26,15 $\mathrm{MPa}$, dan serat 3 lapis dengan kekuatan tarik 26,15 MPa (Jepri, 2016).

Berdasarkan penelitain yang sudah dipaparkan maka belum didapatkan penggunaan limbah bawang untuk dijadikan komposit. Sehingga dapat dilakukan hilirisasi antara penelitian dan pengabdian masyarakat yang berfokus pada pemanfaatan limbah bawang menjadi komposit. Pengabdian masyarakat ini bertujuan untuk menerapkan model pelatihan kepada kelompok masyarakat di Desa Pesantunan dan Desa Bangsri tentang pemanfaatan limbah bawang dijadikan komposit.

\section{METODE PELAKSANAAN}

Tahapan atau langkah-langkah dalam melaksanakan program ini dapat dilihat pada gambar 1.

\section{a. Identifikasi Masalah.}

Langkah awal dalam pengaplikasian limbah bawang menjadi komposit adalah tim membuat dan mengujicobakan dulu sampai berhasil kemudian mempersiapkan bahan dan alat-alat yang dibutuhkan kemudian dilakukan pelatihan pada warga untuk memproduksi alat-alat rumah tangga dari bahan baku limbah bawang sendiri. Sehingga dalam hal ini tugas tim PKM yang pertama adalah mengidentifikasi permasalahan, menganalisa, merancang dan mengaplikasikan alat. Sedangkan tugas dari mitra adalah membantu dalam penyiapan limbah bawang, juga memberikan informasi berhubungan dengan bahan dan alat-alat lain yang dibutuhkan.

Pemahaman warga tentang kegiatan ini juga perlu disosialisasikan agar tidak salah persepsi, kemudian tentang manajemen atau pengaturan dalam pengumpulan limbahlimbah bawang juga diperlukan sehingga kuantitas dalam penyiapan pembuatan produk dapat berjalan dengan lancar, sehingga pelatihan akan manajemen pelaksanaan dan produksi tidak terhambat. 
SPEKTA

Jurnal Pengabdian Kepada Masyarakat : Teknologi dan Aplikasi

Vol. 2, No. 1, Juni 2021

\section{b. Solusi yang Ditawarkan}

Berdasarkan permasalahan yang ada maka secara umum solusi yang ditawarkan dibagi dua yaitu Program Non Fisik atau Soft Program dan Program Fisik atau Hard Program.

1. Soft Program merupakan program-program pelatihan sebelum praktek pelatihan pembuatan produk, kegiatan meliputi sosialisasi, penyampaian materi tentang komposit dan manajemen pengelolaan produksi.

2. Hard Program merupakan kegiatan pelatihan pembuatan produk menggunakan bahan dasar komposit dari serbuk limbah bawang.

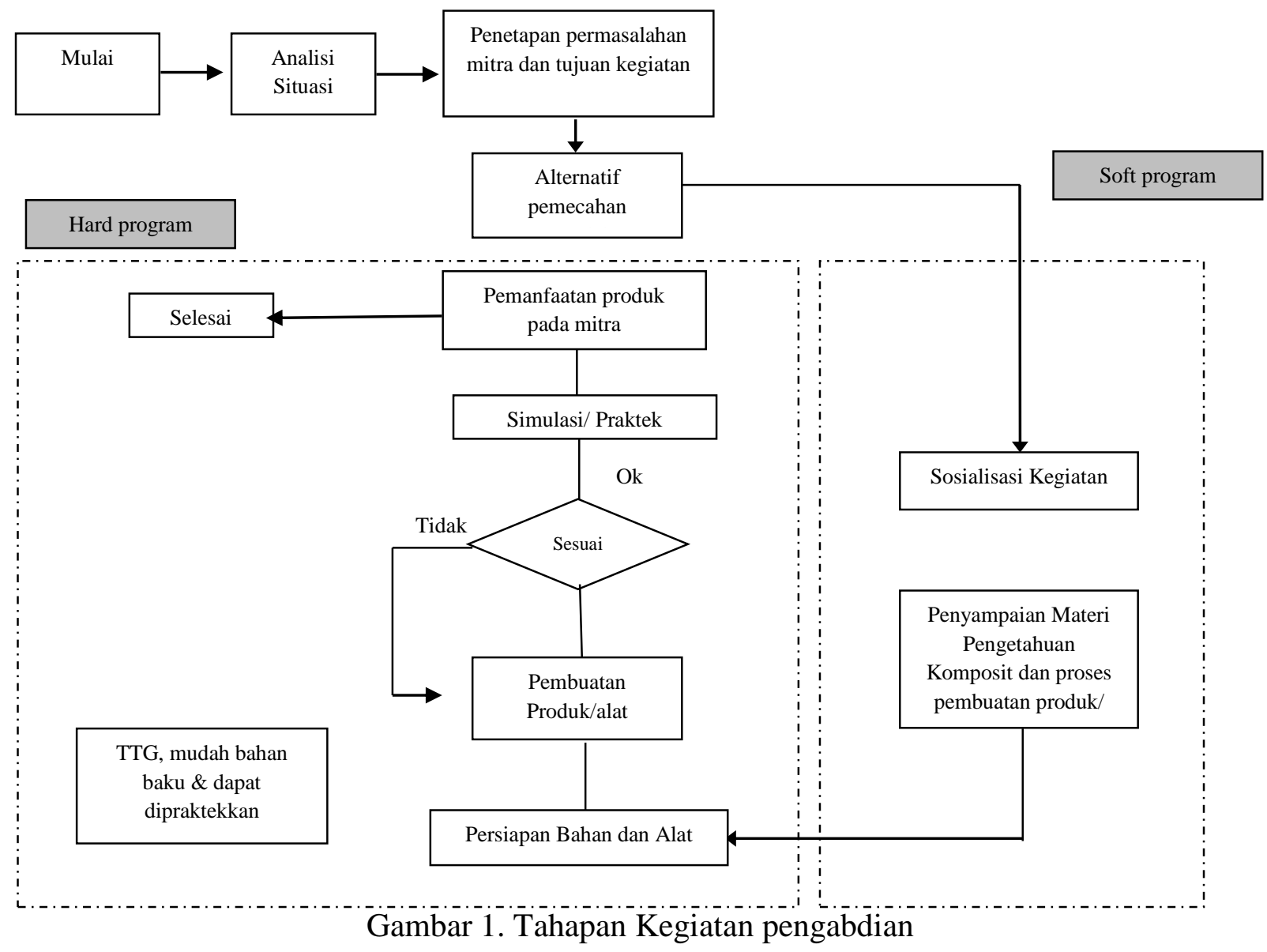

HASIL DAN PEMBAHASAN

1. Program Non Fisik (Soft Program)

a. Tahap Sosialisasi Kegiatan

Pada tahap ini tim melakukan koordinasi dan komunikasi dengan pihak Desa terkait kegiatan Desa Inovasi tersebut (gambar 2 dan gamabr 3). Koordinasi dan komunikasi dilakukan secara intensif supaya kegiatan bisa berlangsung dengan baik dan sesuai keinginan dan harapan dari kelompok warga sasaran kegiatan tersebut. Kelompok masyarakat sasaran di Desa Pesantunan adalah kelompok masyarakat "Santun Asri" yang sudah punya wadah yaitu Bank Sampah dengan jumlah kurang lebi 15 peserta. Adapun keinginan dari kelompok masyarakat tersebut adalah membuat pernak pernik dan juga media tanam/pot yang terbuat dari komposit dikarenakan banyak peserta dari kelompok wanita. 
SPEKTA

Jurnal Pengabdian Kepada Masyarakat : Teknologi dan Aplikasi

Vol. 2, No. 1, Juni 2021

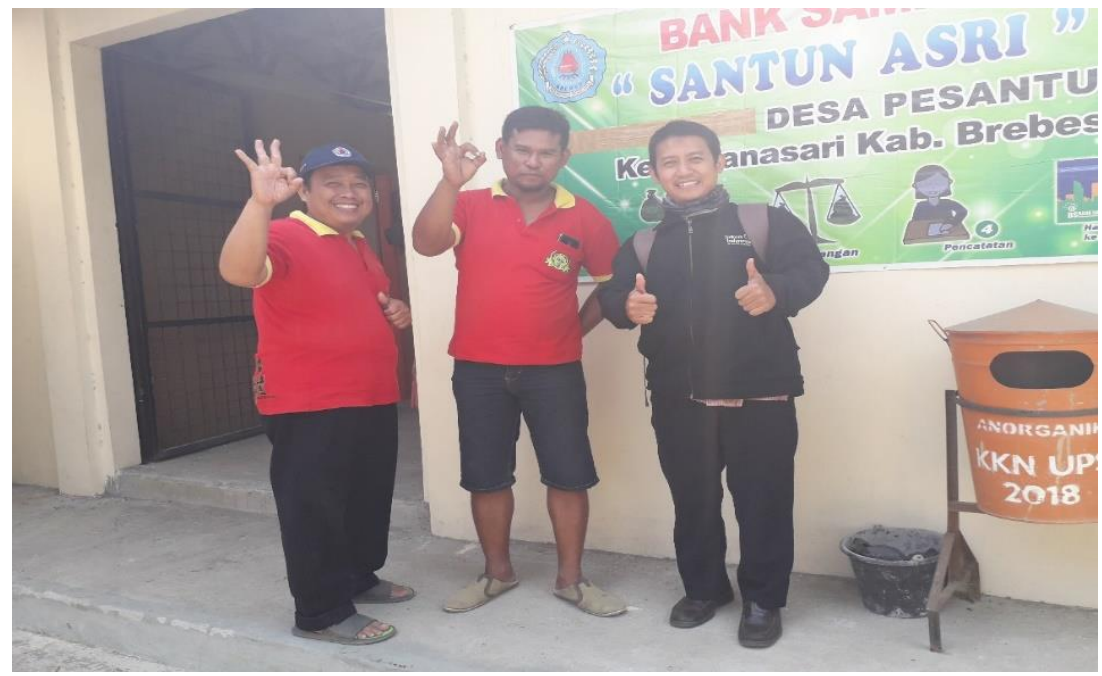

Gambar 2. Koordinasi awal dengan pengurus Bank Sampah Santun Asri

Kelompok masyarakat sasaran di Desa Bangsri adalah kelompok masyarakat yang tergabung dalam Badan Usaha Milik Desa (BUMDES) dengan jumlah peserta kurang lebih 15 orang. Adapun keinginan dari kelompok masyarakat tersebut adalah membuat pernak asbak, pernak pernik dan juga logo atau tulisan "Nahdlatul Ulama" yang terbuat dari komposit dikarenakan banyak peserta dari kelompok laki-laki dan ada program "satu rumah satu logo NU".

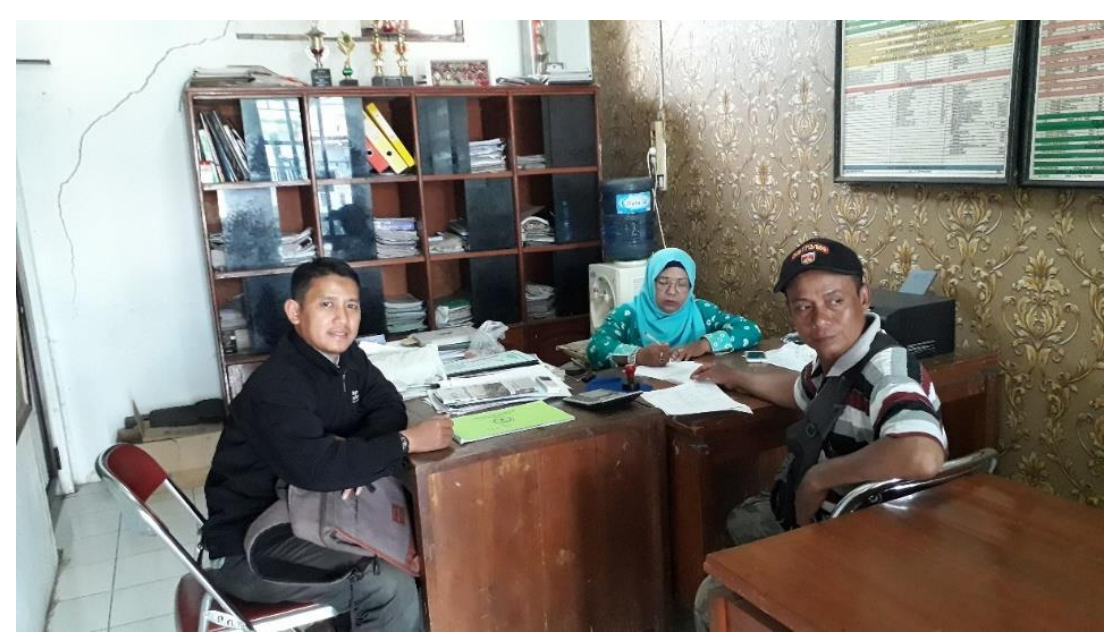

Gambar 3. Koordinasi awal dengan aparat desa Bangsri

b. Penyampaian Materi Pengetahuan tentang Komposit

Tahap yang kedua adalah tahap penyampaian materi yaitu tentang menjelaskan pengetahuan tentang Komposit khususnya penggunaan limbah daun bawang sebagai dasar matrix nya (gambar 4 dan gambar 5). Materi diberikan secara oral dan gambar melalui tampilan Powerpoint dan juga video-video yang menampilkan inovasi penggunaan matrix. Adapun materi yang disampaikan antara lain:

1. Model pengelolaan sampah

Materi ini berisi tentang paradigma sampah rumah tangga, Penanganan melalui CBSWM (Community Based Solid Waste Management), Pengelolaan sampah dari 
Vol. 2, No. 1, Juni 2021

High technology dengan memanfaatkan peralatan separator dan lain sebagainya sampai pengelolaan sampah Low technology.

2. Manajemen Pengelolaan Sampah

Materi ini berisi konsep serta dasar hukum dalam manajemen sampah dengan konsep SWOT (Strength, Weakness, Oppurtinites, Treatment), Sistem dan mekanisme peran masyarakat, dan Faktor keberhasilan dalam manajemen sampah.

3. Desa Inovasi Teknologi Penggunaan Komposit dari Limbah bawang

Materi ini berisi materi teknis penjelasan tentang Komposit, berbagai macam bahan Reinforcement dan Matrixnya serta berbagai macam tutorial pembentukan spesimen menggunakan komposit. Pada tahapan ini kelompok peserta dikenalkan berbagai macam jenis bahan dan peralatan yang digunakan dalam pembuatan komposit dari limbah daun bawang. Pada tahapan ini juga mengkomunikasikan produk apa yang akan dibuat untuk materi praktek yang disesuaikan dengan kebutuhan dan keinginan masyarakat sasaran.
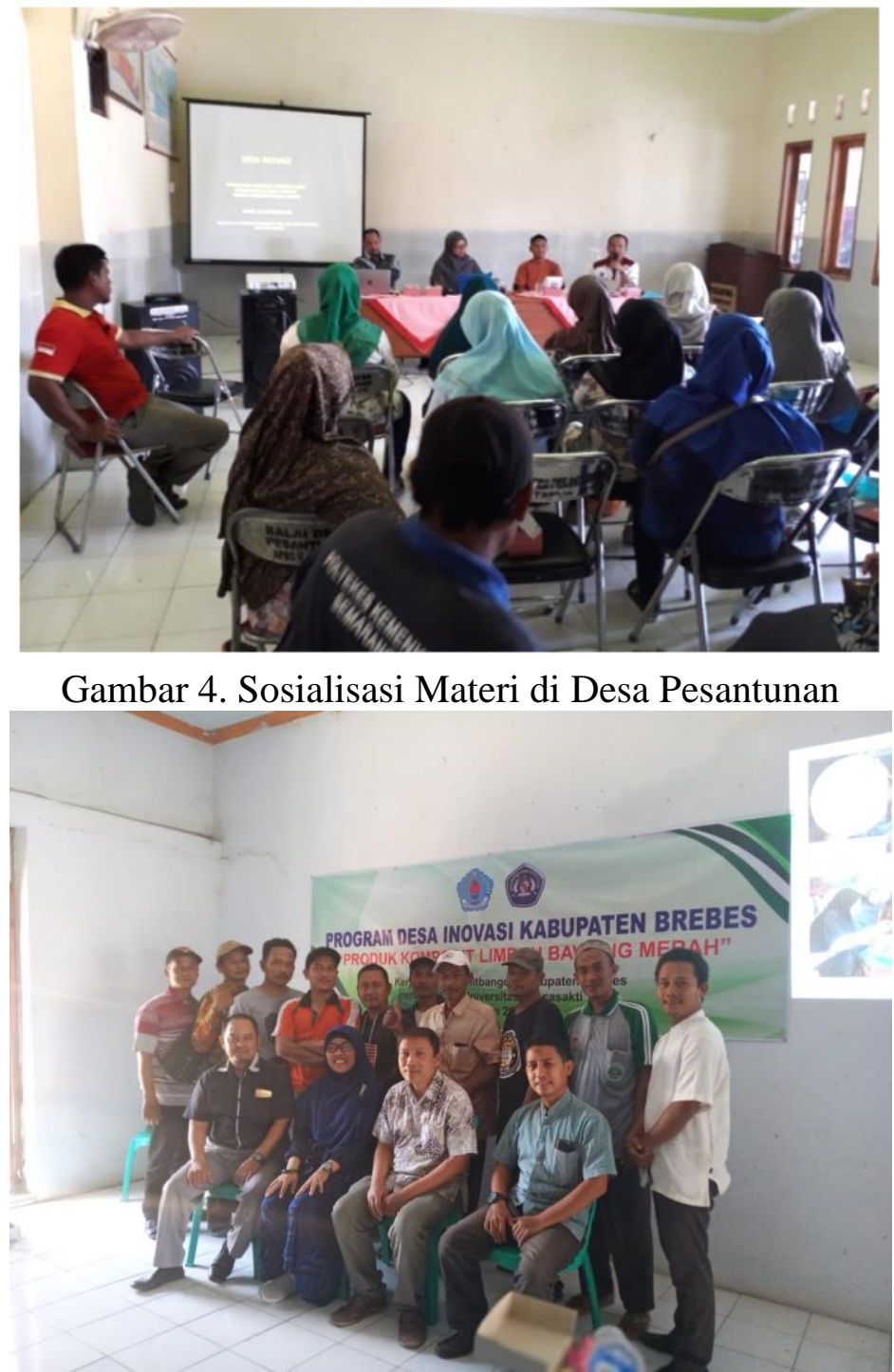

Gambar 5. Pemberian materi di Desa Bangsri 
Vol. 2, No. 1, Juni 2021

\section{Program Fisik (Hard Program)}

Pada tahapan ini peserta diberikan pelatihan pembuatan produk jadi menggunakan komposit dengan limbah daun bawang sebagai reinforcement nya gambar 6 dan gambar 7. Pada tahapan ini tim dari LPPM UPS Tegal mempersiapkan cetakan dan bahan serta peralatan untuk praktek. Persiapan cetakan, bahan dan peralatan yang dibutuhkan disesuaikan keinginan dari kelompok sasaran yaitu membuat pernak pernik. Tahapan awal dari praktek ini antara lain:

a. Pembuatan serbuk limbah daun bawang

b. Penyampuran antara resin dengan hardener dengan perbandingan 1:1

c. Pencampuran reinforcment serbuk limbah daun bawang dengan komposit dan pengadukan supaya merata.

d. Setelah dilakukan pengadukan antara resin, hardener dengan komposit adonan dituangkan ke dalam cetakan yang telah dipersiapkan.

e. Tunggu hingga campuran tersebut mengering dengan dibiarkan begtu saja tanpa ada pengeringan menggunakan matahari.

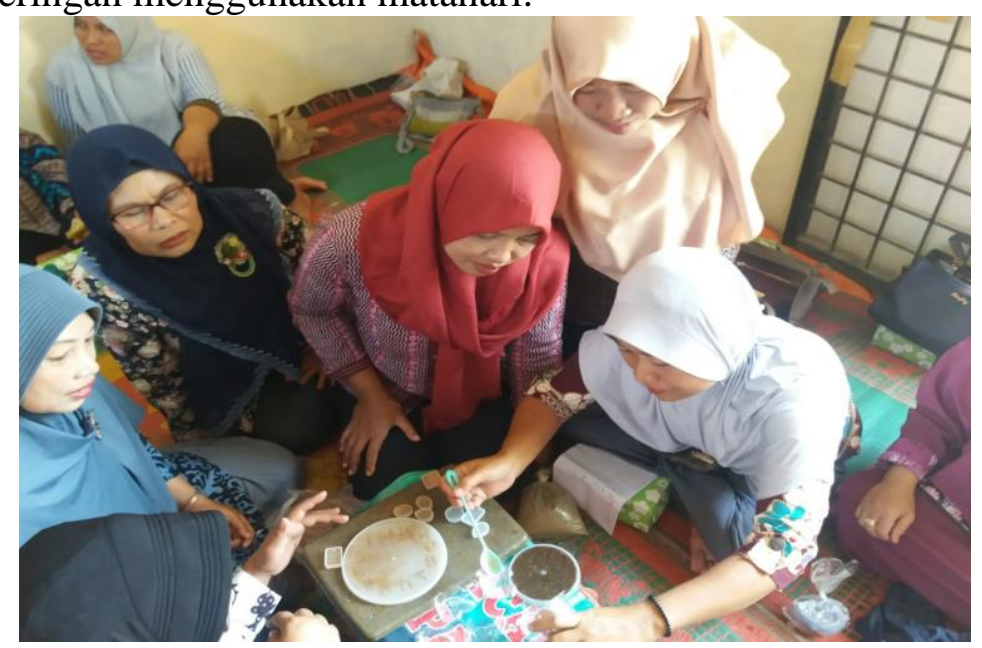

Gambar 6. Peserta di Desa Pesantunan melakukan praktek permbuatan pernak pernik

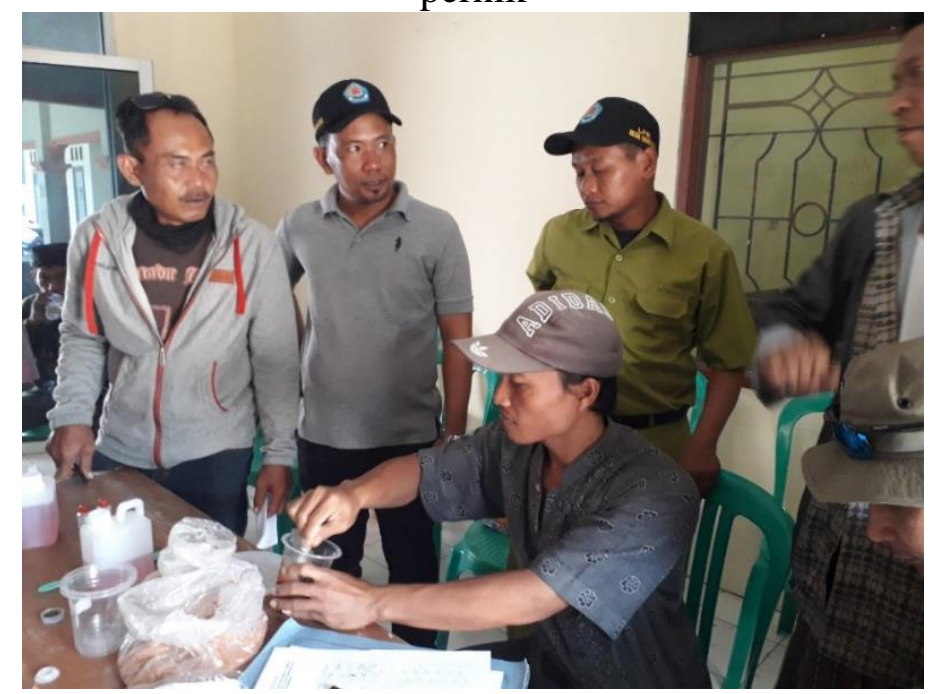

Gambar 7. Peserta dari Desa bangsri melakukan praktek pembuatan komposit untuk pencetakan asbak. 
Vol. 2, No. 1, Juni 2021

\section{Evaluasi Kegiatan Desa Inovasi}

Pada tahapan ini adalah evaluasi pelaksanaan kegiatan Desa Inovasi Teknologi komposit dengan limbah daun bawang sebagai reinforcement nya. Evaluasi dilakukan pada saat praktek, yaitu dengan melihat kondisi langsung peserta melakukan praktek dan evaluasi pasca praktek.

Pada saat praktek banyak dari peserta yang melakukan kesalahan dalam pencampuran komposit tersebut. Kesalahan dikarenakan komposisi antara hardener dengan resin yang tidak sesuai sehingga proses pembentukan komposit tidak sesuai harapan dn proses pengeringan juga akan lama. Kesalahan lainnya adalah pada saat proses pencampuran reinforcement nya yang tidak merata dan terlalu banyak sehingga pembentukan komposit menjadi tidak beraturan. Hasil dari praktek pembuatan komposit dapat dilihat pada gambar 8 dan gambar 9 .

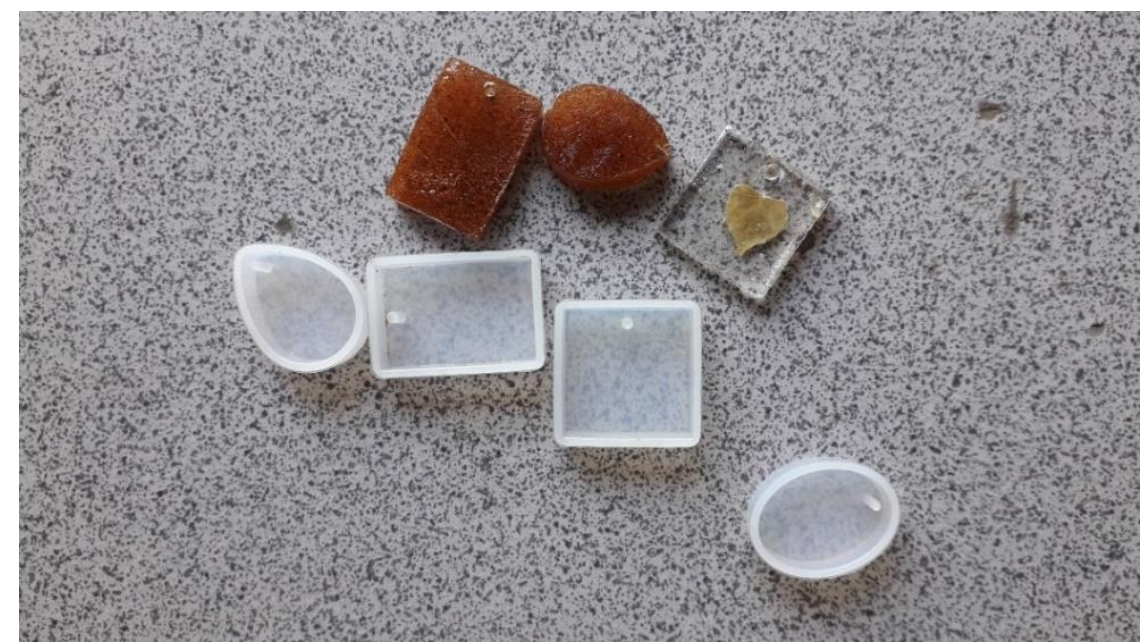

Gambar 8. Hasil Praktek di Desa Pesantunan

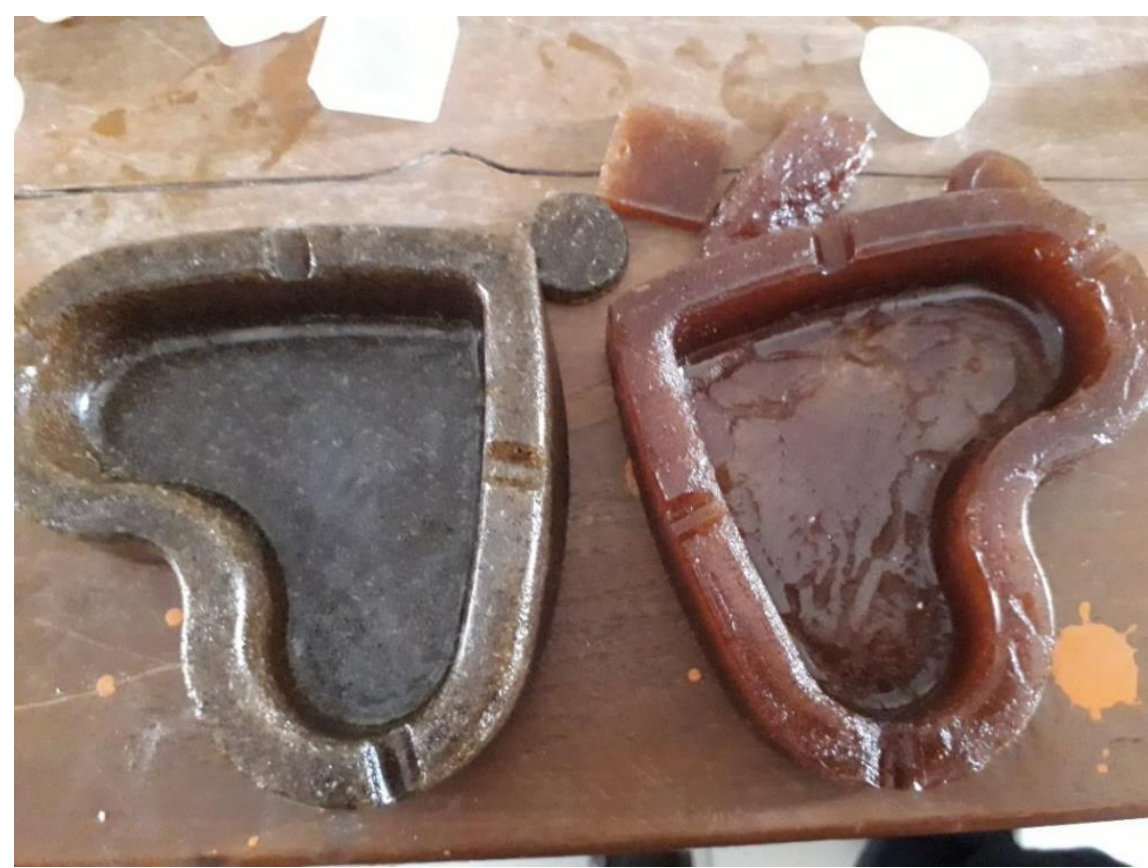

Gambar 9. Hasil Praktek di Desa Bangsri 
Vol. 2, No. 1, Juni 2021

Evaluasi pasca kegiatan dilakukan untuk bisa memantau perkembangan kelompok sasaran terhadap pelatihan baik soft program dan hard program yang sudah diberikan. Pada evaluasi pasca kegiatan untuk di Desa Pesantunan kelompok masyarakatnya masih antusias membuat produk-produk dari komposit terutama untuk pernak pernik maupun pembuatan pot bunga dikarenakan pernak pernik yang dihasilkan bisa dijual dan bisa menambah pendapatan keluarga dan pembuatan pot bunga bisa difungsikan sebagai hiasan khususnya tempat bunga yang terbuat dari limbah sampah.

Sedangkan di Desa bangsri kegiatan pasca pelatihan adalah pembuatan logo Nahdlatul Ulama, dimana cetakan dari logo tersebut sampai laporan ini dibuat pembuatan untuk cetakan logo tersebut masih belum selesai dan masih dalam tahap desain dan pencetakan di computer (gambar 10 dan gambar 11).

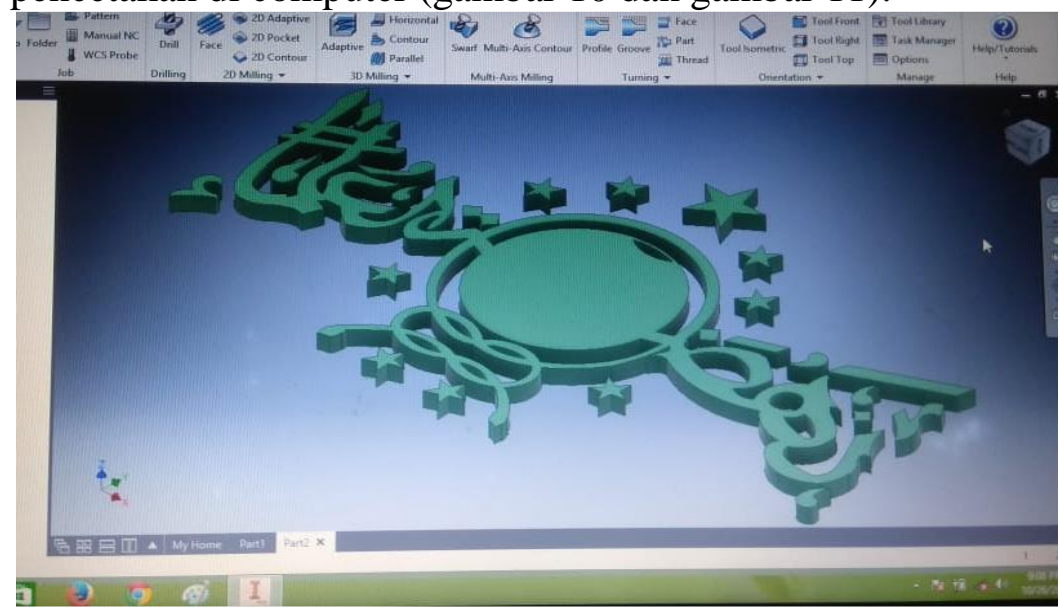

Gambar 10. Desain dan proses Simulasi pembuatan Logo NU

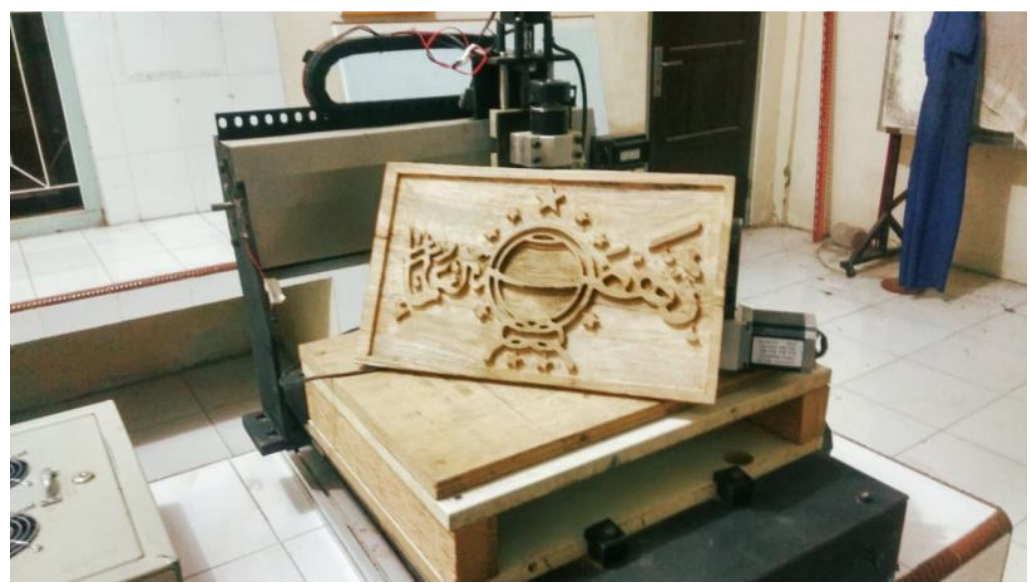

Gambar 11. Proses pembuatan cetakan dengan papan

Secara umum antusiasme kelompok sasaran dari masing-masing desa sudah bagus hanya saja ketergantungan di dalam pengadaan barang serta alat dan bahan masih sangat tinggi, artinya sebelum ada alat dan bahan yang disediakan tim kelompok peserta tersebut masih enggan melakukan praktek pengembangan komposit.

\section{Analisa usaha produk TTG komposit limbah bawang}

Hasil produk teknologi tepat guna yang diterapkan dalam program Desa Inovasi Teknologi diharapkan mampu memberikan dampak terhadap peningkatan perekonomian masyarakat sasaran kegiatan. Peningkatan perkeonomian ini dapat 
SPEKTA

Jurnal Pengabdian Kepada Masyarakat : Teknologi dan Aplikasi

Vol. 2, No. 1, Juni 2021

dilakukan dengan melakukan pemasaran oleh warga (Budiyanto, 2020). Analisa usaha dapat dilihat pada tabel 1, tabel 2, dan tabel 3.

Tabel 1. Kebutuhan Investasi

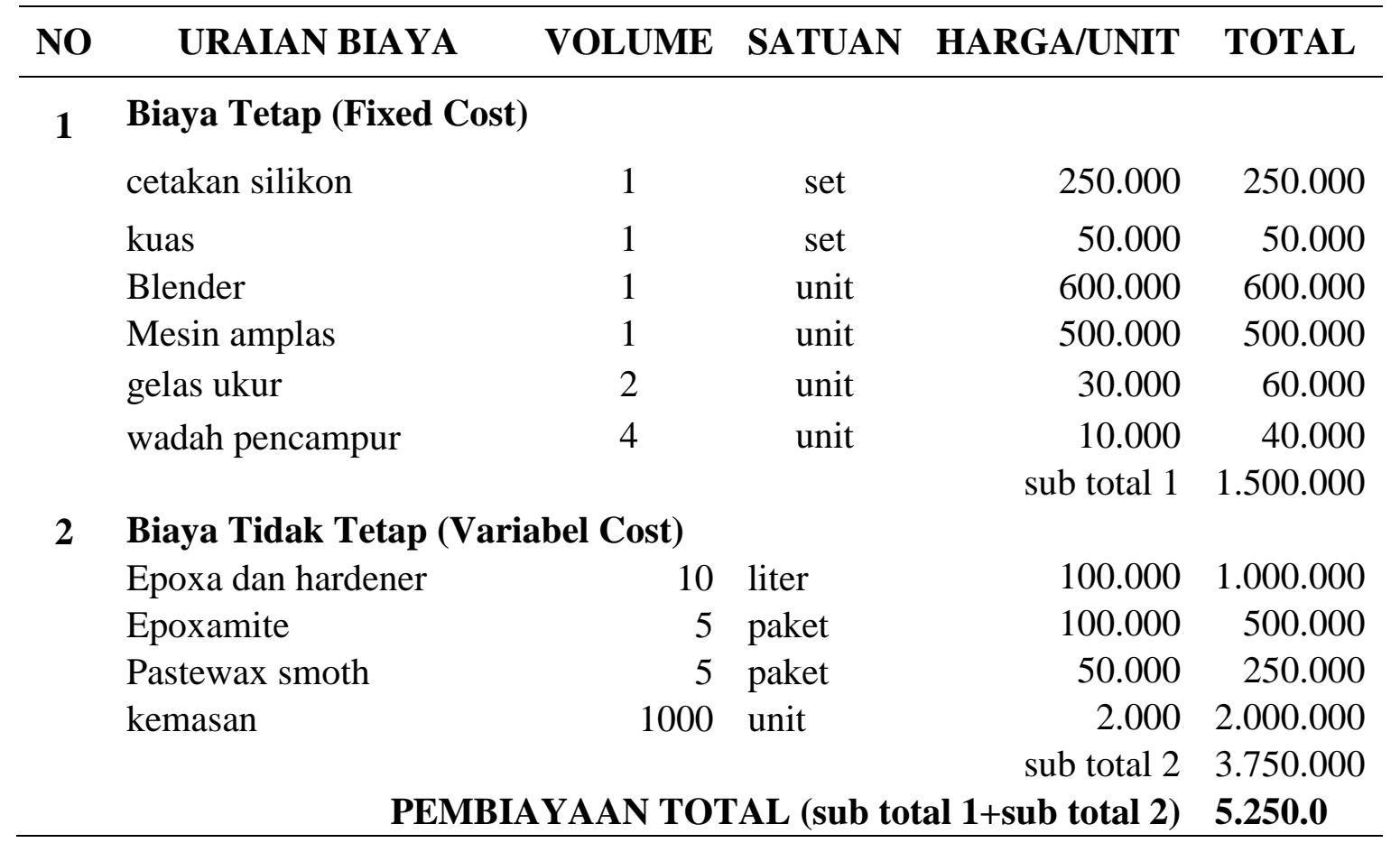

Tabel 2. Perhitungan Analisa Usaha

\begin{tabular}{clcccc}
\hline NO & URAIAN BIAYA & VOLUME & SATUAN & HARGA/UNIT & JUMLAH \\
\hline $\mathbf{1}$ & PENDAPATAN & & & & \\
& Gantungan Kunci & 500 & unit & 6.000 & 3.000 .000 \\
& Bros & 500 & unit & 6.000 & 3.000 .000 \\
& Sub total & & & & 6.000 .000 \\
$\mathbf{2}$ & HPP & & & \\
& modal kerja + & 1 & siklus & 3.900 .000 & 3.900 .000 \\
& insvestasi & & & & 390.000 \\
& penyusutan 10\% & & & Total & 4.290 .000 \\
& Keutungan bersih & & & & 1.710 .000 \\
\hline
\end{tabular}

Tabel 3 Perhitungan Kelayakan Usaha

\begin{tabular}{cccccl}
\hline No & $\begin{array}{c}\text { Aspek } \\
\text { kelayakan } \\
\text { Usaha }\end{array}$ & $\begin{array}{c}\text { Jumlah } \\
\text { item }\end{array}$ & Harga jual & Nilai & Keterangan \\
\hline 1. & BEP Harga & 500 unit & 6.000 & 4.290 & $\begin{array}{l}\text { Nilai impas harga jual } \\
\text { produk minimal Rp. } \\
\end{array}$ \\
& & & & 4.290 \\
\hline
\end{tabular}


Vol. 2, No. 1, Juni 2021

\begin{tabular}{|c|c|c|c|c|c|}
\hline 2 & BEP Unit & 500 unit & 6.000 & 715 & $\begin{array}{l}\text { Nilai impas kuantitas } \\
\text { produksi minimal } 715 \\
\text { unit }\end{array}$ \\
\hline 3 & $\mathrm{R} / \mathrm{C}$ & & & 1.40 & $\begin{array}{l}\text { Ratio Cost } \\
\text { menguntungkan }\end{array}$ \\
\hline 4 & ROI & & & $40 \%$ & $\begin{array}{l}\text { Nilai pengembalian } \\
\text { investasi dari Rp } 1.000 \\
\text { adalah Rp } 400\end{array}$ \\
\hline 5 & PP & & & 3 bulan & $\begin{array}{l}\text { Masa pengembalian } \\
\text { modal adalah } 3 \text { bulan }\end{array}$ \\
\hline
\end{tabular}

Dari analisa usaha diatas maka pemanfaatan limbah bawang dijadikan komposit untuk pembuatan produk-produk aksesoris ataupun produk lainnya memungkinkan untuk dikembangkan dan dijadikan komuditas usaha bagi para petani limbah bawang khususnya petani bawang di Desa Pesantunan dan Desa Bangsri untuk mewujudkan Desa Inovasi Teknologi.

\section{KESIMPULAN}

Pelaksanaan kegiatan Desa Inovasi Teknologi terbagi menjadi beberapa program yaitu Soft Program dan Hard Program. Dimana Soft Program meliputi pemberian materi tentang limbah, sampah serta komposit resin dan daun bawang. Sedangkan Hard Program meliputi praktek bagaimana pembuatan komposit dari limbah daun bawang. Pembuatan komposit dari limbah daun bawang langkahnya yaitu menyiapkan limbah bawang dijadikan serbuk; pengayakan dengan mesh saringan 0.5 ; pencampuran antara resin dengan hardener komposisi $40 \%$ dan dengan serbuk limbah bawang 60\%; pengadukan komposit; penuangan di cetakan dan pengeringan. Pembuatan produk komposit lebih mengutamakan keinginan masyarakat peserta dimana di Desa Pesantunan menginginkan produk komposit yang dibuat adalah pernak pernik serta pot. Sedangkan di Desa Bangsri menginginkan produk komposit yang dibuat adalah asbak dan logo Nahdlatul Ulama. Evaluasi kegiatan pada saat praktek masih banyak kesalahan khususnya dipencampuran komposisi antara resin, hardener serta reinforcement nya sehingga hasil komposit tidak maksimal masih tidak beraturan dalam sebaran reinforcementnya serta lama kering. Evaluasi pasca kegiatan dimasing-masing desa bahwa peserta masih enggan melakukan pengembangan komposit dikarenakan masih ketergantungan khususnya pengadaan alat dan bahan pembuatan komposit yang diinisiasi dari tim pengusul dan belum ada inisiasi membuat produk komposit sendiri. Keberhasilan program untuk mewujudkan Desa Inovasi Teknologi sangat bergantung dari partisipasi, keaktifan, inisiatif serta kreatifitas masyarakat penerima manfaat program. Jadi harapannya masyarakat lebih aktif untuk mewujudkannya. Diperlukan riset berkelanjutan utamanya dalam mendesign produk yang marketable (tangible \& intangible) sehingga dapat memberikan dampak perubahan perekonomian bagi masyarakat penerima manfaat program.

\section{UCAPAN TERIMA KASIH}

Ucapan terima kasih kepada Bapperlitbangda Kabupaten Brebes Propinsi Jawa Tengah yang telah membiayai pelaksanaan kegiatan Pengabdian Kepada Masyarakat ini. 
Vol. 2, No. 1, Juni 2021

\section{DAFTAR PUSTAKA}

Abanat, J.D.J., Purnowidodo, A. \& Irawan, S.Y. 2012. Pengaruh Fraksi Volume Serat Pelepah Gebang (Corypha Utan Lamarck) Terhadap Sifat Mekanik Pada Komposit Bermatrik Epoksi. Jurnal Rekayasa Mesin, 3(2): 352-361.

Amin, M. \& Samsudi. 2010. Pemanfaatan Limbah Serat Sabut Kelapa Sebagai Bahan Pembuat Helm Pengendara Kendaraan Roda Dua. Prosiding Seminar Nasional Unimus 2010. Universitas Muhahammadiyah Semarang: 314-318.

Arfan, R. et al. (2020) "Peran ukm dalam menstabilkan harga masker sebagai bentuk pencegahan penyebaran covid-19 di banda aceh," SPEKTA (jurnal Pengabdian Kepada Masyarakat: Teknologi dan Aplikasi), 1(1), pp. 31-34.

Astika, I.M., Lokantara, I.P. \& Karohika, I.M.G. 2013. Sifat Mekanis Komposit Polyester dengan Penguat Serat Sabut Kelapa. Jurnal Energi dan Manufaktur, 6(2): 95-202.

Badan Pusat Statistik Kabupaten Brebes. 2015. Brebes Dalam Angka. Nomor Katalog 1102001.3329.

Budiyanto, T. (2020) "Strategi Pemasaran Usaha Kecil Menengah Pada Ibu-Ibu Aisyiah Muhammadiyah Bali," SPEKTA (Jurnal Pengabdian Kepada Masyarakat: Teknologi dan Aplikasi), 1(1), p. 17. doi: 10.12928/spekta.v1i1.2649.

Dhiki Ramadhani. 2011. Material Komposit Berpenguat Serat Alam. Universitas Indonesia. Jepri. 2016. Karekteristik Kekuatan Komposit Serat Kulit Pohon Terap Dengan Variasi Jumlah Lapisan Serat. Universitas Sanatha Dharma Yogyakarta.

Kementrian Desa. Peraturan No 23 Tahun 2017 tentang Pengembangan dan Penerapan Teknologi Tepat Guna Pedesaan.

Robert L Mott. 2009. Elemen Mesin dalam Perancangan Mekanis. Penerbit Andi Yogyakarta. Suwandi. 2016. Statistik Pertanian Agricultural Statistics 2016. Pusat Data Informasi Pertanian Kementrian Pertanian republik Indonesia.

Suhono. 2016. Potensi Bawang Merah di Kabupaten Brebes. Repository. Universitas Muhammadiyah Yogyakarta.

Wahdan Kurniawan. 2011. Karakterisasi Material Komposit Jerami-Epoksi. Universitas Pasundan Bandung.

Setyawan, P.D., Sari, N.H. \& Putra D.G.P. 2012. Pengaruh Orientasi dan Fraksi Volume Serat Daun Nanas (Ananas Comosus) Terhadap Kekuatan Tarik Komposit Polyester Tak Jenuh (UP). Dinamika Teknik Mesin, 2(1): 28-32.

Sirait, D.H. 2010. Material Komposit. Penerbit: Erlangga. Jakarta.

Soemardi, T.P., Kusumaningsig, W. \& Irawan, A.P. 2009. Karakteristik Mekanik Komposit Lamina Serat Rami Epoksi Sebagai Bahan Alternatif Soket Prostesis. MAKARA TEKNOLOGI, 13(2): 96-101.

Suryanto, H., Irawan, Y.S., Marsyahyo, E. \& Soenoko, R. 2013. Karakteristik Serat Mendong (Fimbristylis globulosa): Upaya Menggali Potensi Sebagai Penguat Komposit Matriks Polimer. National Conference Green Technology 3, November 2013. 
SPEKTA

Jurnal Pengabdian Kepada Masyarakat : Teknologi dan Aplikasi

Vol. 2, No. 1, Juni 2021

Halaman ini sengaja dikosongkan

This page is intentionally left blank. 